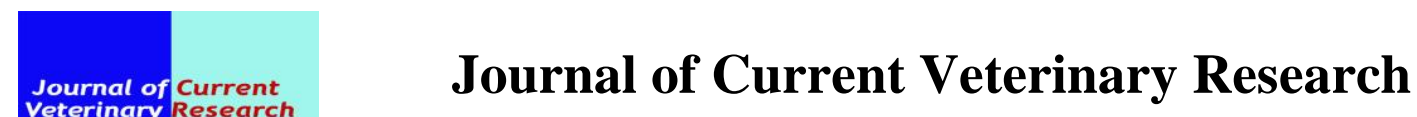

ISSN:4026-2636

Journal homepage: http://www.jcvr.journals.ekb.eg

\title{
Morphopathological and Biochemical Changes Induced by Cisplatin as Anticancer Drug and The Protective Role of Moringa Leaf Ethanolic Extract and L-Carnitine in Rat
}

\author{
Hamdy A. Salem, Enas A. Tahoun*, Anhar A. Kamel \\ Department of pathology, Faculty of Veterinary Medicine, University of Sadat City.
}

* Corresponding Author: enastahoon35@yahoo.com Submitted: 3 April 2018 Accepted: 5 May 2019

\begin{abstract}
:
Cisplatin is a potent, highly effective, broad spectrum chemotherapeutic agent, its clinical application is limited due to its adverse effects on normal tissues Since the pathogenesis of cisplatin-induced toxicities mainly involve free radical and lipid peroxidation, this study was designed to evaluate the protective efficacy of Moringa leaf ethanolic extract and Lcarnitine against cisplatin-nephrotoxicity and hepatotoxicity in rats. 72 male albino rats were divided into 6 groups GI- control received no treatment, GII- cisplatin $(7 \mathrm{mg} / \mathrm{kg}$ for 4 days), GIII- Prophylaxis by Moringa (500mg/kg for 10 days) then cisplatin as in G2, GIVProphylaxis by L-Carnitine (200 mg/kg for 10 days) then cisplatin as in G2, GV- treatment by Moringa received cisplatin as group II plus Moringa extract for 14 days. VI- treatment by L-Carnitine received cisplatin as group II plus L-Carnitine for 14 days. The results indicate that cisplatin induced significant increase in serum ALT, AST, Urea, Creatinine and kidney MDA level, also significant decrease in kidney GSH and CAT levels and histopathological changes in kidney tissues as cloudy swelling, necrobiosis changes of tubular epithelium, congestion of glomerular tuft, also hepatic lesions as congestion of the central and portal vein with necrosis of its lining intimal cells, formation of newly formed bile duct with lymphocytic cell infiltrations in portal area and coagulative necrosis of some hepatocytes and another hepatocytes showed hydropic degeneration. Both moringa leaf ethanolic extract and L-carnitine ameliorated these toxicities as evidenced by restoring normal serum ALT, AST, Urea, Creatinine and histopathological architecture of kidney and liver.
\end{abstract}

Keywords: Cisplatin, Moringa, L-carnitine, Oxidative stress, Histopathology.

\section{INTRODUCTION:}

Cisplatin is a prototype of several thousand platinum compounds (Reedijk, 2011), and is one of the most effective broad-spectrum chemotherapeutic agents which plays a major role in the treatment of a variety of human malignant tumors (Ma et al., 2017). Despite its clinical usefulness, its Clinical use was restricted because of more specific toxic side effects include nephrotoxicity (Hagar et al., 2015), hepatotoxicity (Waseem et al., 2015), neurotoxicity (Eken et al., 2014), cardiovascular toxicity (Saleh et al., 2014) and testicular toxicity (Atessahin et al., 2006).

L-carnitine is a vitamin like substance that is structurally similar to amino acids. It is known that L-carnitine and its derivatives prevent the formation of reactive oxygen species (ROS) and protect cell against free radical damage, lipid peroxidation and oxidative stress
(Kolodziejczyk et al., 2011; Cao et al., 2011; Lee et al., 2014). The protective effects of Lcarnitine (LC) on changes in the levels of lipid peroxidation and endogenous antioxidants induced by cisplatin in the liver and kidney tissues of rats was investigated by (Al-Majed $e t$ al., 2007; Aleisa et al., 2007)

Moringa oleifera (M. oleifera) or drumstick is a member of Moringaceae, and it is grown extensively in many Southeast Asian countries (Leone et al., 2015). Moringa oleifera consists of anti-inflammatory, antihypertensive, antispasmodic, antioxidant, antitumor antipyretic, anti-ulcer, anti-epileptic, diuretic, cholesterol lowering, anti-diabetic, (Paliwal et al., 2011; Sharma et al., 2012), nephroprotective (Ouedraogo et al., 2013) and hepatoprotective activities (Hamza, 2010). 


\section{MATERIALS AND METHODS:}

\section{Experimental animals:}

The present work was carried out on 72 male albino rats, their body weights ranged from (150 to 200g). They were obtained from ALZyade Experimental Animals Production Center, Giza, Egypt were used in this study. All animals were clinically healthy and were acclimatized for two weeks in plastic cages with galvanized iron filter tops and placed in quiet room with natural ventilation. Clean food and water were given to rats ad libitum throughout the experimental period, and the bedding material of cages was changed every day.

\section{Chemicals:}

Cisplatin was purchased from local pharmacy manufactured by Merck Company, in the form of vials, each vial contains $50 \mathrm{mg} / 50 \mathrm{ml}$ cisplatin. L-carnitine was purchased from local pharmacy manufactured by MEPACO Company, Egypt in the form of syrup (200 $\mathrm{mg} / \mathrm{ml}$ syrup). Moringa Oleifera leaves was obtained from botanical garden, Sadat city, Egypt. Diagnostic kits for assaying serum biochemical parameters (ALT, AST, Urea, Creatinine) and oxidative stress markers in kidney tissue (MDA, GSH, CAT) were obtained from Biodiagnostic Company, Dokki, Giza, Egypt.

\section{Preparation of Moringa leaf extracts} (Ethanolic extract).

The leaves of Moringa oleifera were collected and dried under shade and grounded into powder. From the powder taken $500 \mathrm{gm}$. and was soaked in ethanol $70 \%$ at room temperature for $24 \mathrm{~h}$. Then it was filtered by Whatman filter paper no.1. The filtrate was evaporated in water bath at $60^{\circ} \mathrm{C}$ to dryness. The color of residue was brownish and weighing $30.5 \mathrm{~g}$. From the extract was taken $15 \mathrm{gm}$ and dissolved in $100 \mathrm{ml}$ distilled water. The dilated extract was administrated orally by stomach tubes to animals in dose $500 \mathrm{mg} / \mathrm{kg}$ body weight as mentioned by (Busani et al., 2012).

Experimental Design: After acclimatization of animals for 2 weeks, 72 rats were classified randomly into 6 groups (Each group contain 12 rats) as shown in Table (1).

1.Group I (Control group): Control -ve served as control received normal food and water without any treatment during the experimental period.
2. Group II (Cisplatin group): Control +ve received $7 \mathrm{mg} / \mathrm{kg}$ B.W. intraperitoneal injection of cisplatin (Ugur et al., 2015) for 4 successive days.

3. Group III (Moringa prophylaxis group): received Moringa ethanolic extract 500 $\mathrm{mg} / \mathrm{kg} \mathrm{B.W}$. (Chinedu et al., 2014) orally by stomach tube as prophylaxis for 10 days then injected cisplatin as group II.

4. Group I (L-Carnitine prophylaxis group): received L-carnitine $200 \mathrm{mg} / \mathrm{kg}$ B.W. (Sleem et al., 2014) orally by stomach tube as prophylaxis for 10 days then injected cisplatin as group II.

5. Group V (Moringa treatment group): received cisplatin as group II plus Moringa extract $500 \mathrm{mg} / \mathrm{kg}$ orally by stomach tube for 14 days.

6. Group VI (L-Carnitine treatment group): received cisplatin as group II plus L-carnitine $200 \mathrm{mg} / \mathrm{kg}$ orally by stomach tube for 14 days.

\section{Scheduled time of sacrifice:}

1- Group II, III, IV and 6 rats from group I were slaughtered at $15^{\text {th }}$ day of the experiment.

2- Group V, VI and 6 rats from group I were slaughtered at $25^{\text {th }}$ day of the experiment.

\section{Sampling:}

Rats were fasted overnight, anesthetized under light Diethyl ether (DEE) and were prepared for collection of samples. Blood samples were collected from the inner canthus of the eye (retro-orbital plexus) of each rat using capillary tubes according to (Schermer, 1967). The collected blood samples were poured gently and carefully on the wall of labeled clean and dry glass centrifuge tubes without using anticoagulant and left for clotting at room temperature for 20 minutes, then centrifuged at $3000 \mathrm{rpm}$ for 15 minutes in a cooling centrifuge. The clean supernatant serum was aspirated by means of automatic pipette into labeled Eppendorf tubes and stored at -20 until the time of analysis. Immediately after blood collection, rats were rapidly sacrificed and tissue specimens from the liver and kidney were collected. The kidney of each rat was divided into two parts; one part was stored at $20^{\circ} \mathrm{C}$ for biochemical assay [MDA level and antioxidant enzymes activities (GSH, CAT)], while the other part was kept in $10 \%$ neutral buffered formalin for histopathological 
examination, also tissue samples from liver was also kept in $10 \%$ neutral buffered formalin.

\section{Biochemical analysis:}

1. Serum alanine aminotransferases (ALT) and Aspartate aminotransferase (AST) enzymatic activity were assayed spectrophotometrically in the serum of all rats according to (Reitman and Frankel, 1957), serum concentration of urea according to (Lile et al., 1957) and creatinine according to (Fabiny and Eringhausen, 1971) using spectrum diagnostic kits following the manufacturer's instructions.

\section{Estimation of kidney}

Malondialdehyde level (MDA) (index of Lipid peroxidation): The lipid peroxidation content in the kidney homogenate was assayed for the measurement of malondialdehyde (MDA) as malondialdehyde- thiobarbituric acid adducts according to the procedure described by (Ohkawa et al., 1979).
3. Estimation of kidney reduced glutathione (GSH) and catalase (CAT) activity: GSH was estimated according to Chanarian, (1989) and CAT activity according to Aebi, (1974).

Histopathological examination:

The formalin fixed specimens were trimmed, washed, dehydrated in ascending grades of ethyl alcohol, cleared in methyl benzoate and embedded in paraffin wax after having completed the routine follow-up steps. Sections at 3-5 $\mu$ sections were obtained from the kidney, liver using microtome (LEICA RM 2135) and stained by hematoxylin and eosin (H\&E) stain for light microscopical investigation according to (Bancroft et al., 2012). Photos were taken using digital camera (LEICA DMLB Germany).

Statistical analysis procedures:

Statistical analysis of data was carried out using analysis of variance in one-way (ANOVA) test followed by LSD and Duncan test. Results were expressed as mean \pm standard error (mean $\pm \mathrm{SE}$ ), according to (Sendecor and Cochran, 1987).

Table (1): The experimental design:

\begin{tabular}{|c|c|c|c|}
\hline \multirow[b]{2}{*}{ Group } & \multicolumn{3}{|c|}{ Days of experiment } \\
\hline & $\begin{array}{l}10 \text { days Before Cisplatin } \\
\text { injection from } 1^{\text {st }} \text { day till } 10^{\text {th }} \\
\text { day of the experiment }\end{array}$ & $\begin{array}{l}4 \text { days Cisplatin injection } \\
\text { from } 11^{\text {th }} \text { day till } 14^{\text {th }} \text { day } \\
\text { of the experiment }\end{array}$ & $\begin{array}{l}10 \text { days After Cisplatin } \\
\text { injection from } 15^{\text {th }} \text { day till } \\
24^{\text {th }} \text { day of the experiment }\end{array}$ \\
\hline Group I (Control) & Without treatment & Without treatment & Without treatment \\
\hline Group II (Cisplatin) & Without treatment & Cisplatin & Without treatment \\
\hline $\begin{array}{l}\text { Group III (prophylaxis by } \\
\text { Moringa then Cisplatin) }\end{array}$ & Moringa & Cisplatin & Without treatment \\
\hline $\begin{array}{l}\text { Group IV (prophylaxis by } \\
\text { L-carnitine then Cisplatin) }\end{array}$ & L-carnitine & Cisplatin & Without treatment \\
\hline $\begin{array}{l}\text { Group V (Cisplatin then } \\
\text { treated by Moringa) }\end{array}$ & Without treatment & Cisplatin+ Moringa & Moringa \\
\hline $\begin{array}{l}\text { Group VI (Cisplatin then } \\
\text { treated by L-carnitine) }\end{array}$ & Without treatment & $\begin{array}{c}\text { Cisplatin+ } \\
\text { L-carnitine }\end{array}$ & L-carnitine \\
\hline
\end{tabular}

\section{RESULTS}

Serum biochemical assay: the obtained data in table (2) revealed that cisplatin group induced highly significant elevation in serum ALT, AST, Urea and Creatinine activity compared to control group. These elevations were ameliorated by administration of antioxidants L-Carnitine or Moringa.

Lipid peroxidation and oxidative stress enzymes: 
The obtained data in table (3) revealed that cisplatin intoxication induced a statistically significant elevation in kidney tissue malondialdehyde (MDA) concentration and also induced a statistically significant reduction in kidney tissue glutathione $(\mathrm{GSH})$ concentration and kidney tissue catalase (CAT) activity compared to control animals. Coadministration of antioxidant L-Carnitine or Moringa provide good results in reduction tissue MDA level and elevation of tissue GSH and CAT activity.

Table (2): Serum biochemical parameters of liver and kidney function:

\begin{tabular}{ccccc}
\hline $\begin{array}{c}\text { Parameter } \\
\text { group }\end{array}$ & $\begin{array}{c}\text { ALT } \\
(\mathbf{U} / \mathbf{L})\end{array}$ & $\begin{array}{c}\text { AST } \\
(\mathbf{U} / \mathbf{L})\end{array}$ & $\begin{array}{c}\text { BUN } \\
(\mathbf{m g} / \mathbf{d l})\end{array}$ & $\begin{array}{c}\text { Creatinine } \\
(\mathbf{m g} / \mathbf{d l})\end{array}$ \\
\hline G I & $37.56 \pm 0.78^{\mathrm{e}}$ & $81.93 \pm 0.63^{\mathrm{d}}$ & $51.00 \pm 0.13^{\mathrm{e}}$ & $0.93 \pm 0.08^{\mathrm{d}}$ \\
G II & $58.00 \pm 1.15^{\mathrm{a}}$ & $125.33 \pm 1.88^{\mathrm{a}}$ & $150.01 \pm 8.49^{\mathrm{a}}$ & $1.86 \pm 0.02^{\mathrm{a}}$ \\
GIII & $43.66 \pm 1.20^{\mathrm{c}}$ & $89.33 \pm 0.88^{\mathrm{c}}$ & $116.66 \pm 3.76^{\mathrm{b}}$ & $1.60 \pm 0.04^{\mathrm{b}}$ \\
G IV & $47.33 \pm 1.20^{\mathrm{b}}$ & $93.66 \pm 1.20^{\mathrm{b}}$ & $77.48 \pm 1.08^{\mathrm{d}}$ & $1.40 \pm 0.01^{\mathrm{c}}$ \\
G V & $42,00 \pm$ & $88.66 \pm 1.20^{\mathrm{c}}$ & $89.90 \pm 0.90^{\mathrm{c}}$ & $1.30 \pm 0.05^{\mathrm{c}}$ \\
G VI & 39.56 & $84.00 \pm 0.57^{\mathrm{d}}$ & $70.95 \pm 1.65^{\mathrm{d}}$ & $1.29 \pm 0.03^{\mathrm{c}}$ \\
\hline
\end{tabular}

All data presented as mean value \pm SE. Values bearing different superscripts $(a, b, c, d, e)$ are Considered significantly different at $\mathbf{P}<\mathbf{0 . 0 5}$, ALT: Alkaline transaminase; AST: Aspartate transaminase.

Table (3) lipid peroxidation and antioxidant enzymes in kidney tissue:

\begin{tabular}{cccc}
\hline $\begin{array}{c}\text { Parameter } \\
\text { group }\end{array}$ & $\begin{array}{c}\text { MDA } \\
(\mathbf{n m o l} / \mathbf{g} \text { tissue })\end{array}$ & $\begin{array}{c}\text { GSH } \\
(\boldsymbol{\mu m o l} / \mathbf{m g ~ t i s s u e ~ p r o t e i n})\end{array}$ & $\begin{array}{c}\text { CAT } \\
(\mathbf{U} / \mathbf{g} \text { tissue protein })\end{array}$ \\
\hline G I & $107.87 \pm 1.82^{\mathrm{e}}$ & $18.62 \pm 0.38^{\mathrm{a}}$ & $3.29 \pm 0.10^{\mathrm{a}}$ \\
G II & $351.53 \pm 1.61^{\mathrm{a}}$ & $12.02 \pm 0.77^{\mathrm{c}}$ & $1.40 \pm 0.07^{\mathrm{c}}$ \\
GIII & $228.33 \pm 1.44^{\mathrm{b}}$ & $14.96 \pm 0.48^{\mathrm{b}}$ & $2.22 \pm 0.16^{\mathrm{b}}$ \\
G IV & $152.43 \pm 2.31^{\mathrm{c}}$ & $16.62 \pm 0.19^{\mathrm{b}}$ & $2.79 \pm 0.14^{\mathrm{b}}$ \\
G V & $148.07 \pm 2.06^{\mathrm{c}}$ & $15.22 \pm 0.60^{\mathrm{b}}$ & $2.76 \pm 0.08^{\mathrm{b}}$ \\
G VI & $124.67 \pm 1.77^{\mathrm{d}}$ & $15.25 \pm 0.61^{\mathrm{b}}$ & $2.59 \pm 0.02^{\mathrm{b}}$ \\
\hline
\end{tabular}

All data presented as mean value \pm SE. Values bearing different superscripts $(\mathbf{a}, \mathbf{b}, \mathbf{c}, \mathbf{d}, \mathbf{e})$ are Considered significant at $\mathbf{P}<\mathbf{0 . 0 5}$, MDA: Malondialdehyde level; GSH: Glutathione concentration; CAT: Catalase activity.

\section{Histopathological findings:}

1. Kidney (Fig. 1): Kidneys of the control rats showed normal histological structure (A) while, kidney sections of cisplatin groups showed severe congestion of glomerular tuft, cloudy swelling of renal tubules with renal casts in lumen, Edema in the interstitial tissue with lymphocytic cell infiltrations around glomeruli and renal tubules (B). Prophylaxis by Moringa showed mild congestion of glomerular tuft and some tubules suffered from cloudy swelling (C). Prophylaxis by L-carnitine showed mild cloudy swelling of some renal tubules, another tubules showed dilatation and somewhat normal glomeruli were observed (D). Treatment by Moringa showed mild congestion of glomeruli and proteinous hyaline casts in the lumen of some renal tubules (E). Treatment by L-
Carnitine showed nearly normal glomeruli and renal tubules (F).

2. Liver (Fig. 2): Normal hepatic tissue architecture was observed in all control rats (A) while, liver of rats treated with Cisplatin showed congestion of the central and portal veins with necrosis of its lining intimal cells, formation of newly formed bile duct with lymphocytic cell infiltrations in portal area and coagulative necrosis of some hepatocytes and another hepatocytes showed hydropic degeneration (B). Prophylaxis by Moringa showed mild congestion of central vein, mild coagulative necrosis of some hepatic cells and mild newly formed bile $\operatorname{duct}(\mathbf{C})$ and prophylaxis by L-Carnitine showed mild congestion of hepatic sinusoids with somewhat normal hepatic cells (D), but treatment by moringa showed mild hydropic degeneration of some hepatic cells (E). L-Carnitine showed nearly normal liver tissue (F). 


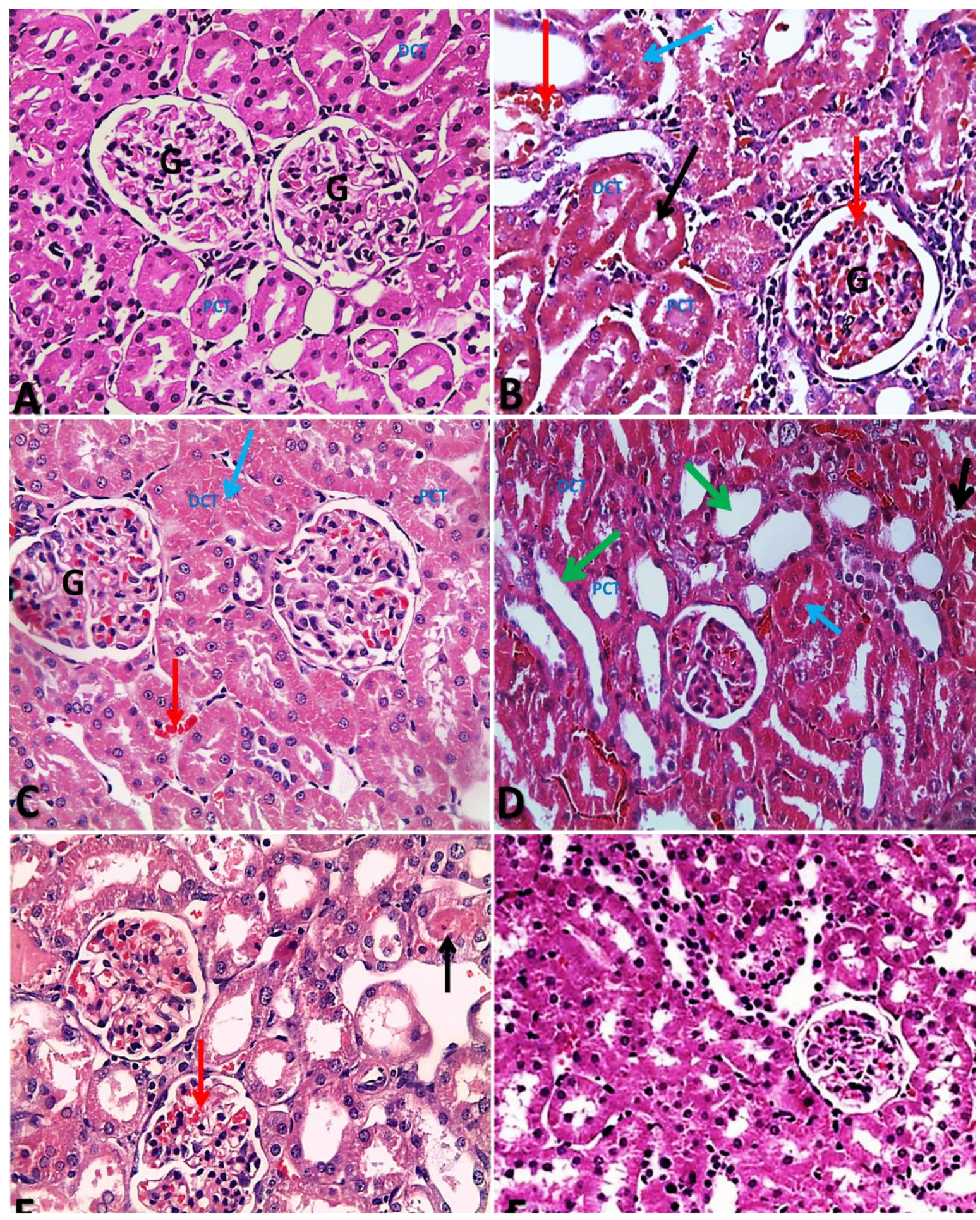

Fig. 1: Kidney of different groups of rats: A (control): showing normal histological architectures (H\&E Stain X40). B (cisplatin): showed severe hemorrhage and congestion of glomerular tuft (red arrows), cloudy swelling of renal tubules (blue arrow) with renal casts in lumen (black arrow), Edema in the interstitial tissue with lymphocytic cells infiltration around glomeruli and renal tubules (H\&E Stain X20). C (M.O prophylaxis group): showing mild hemorrhage and congestion of glomerular tuft (red arrow) and some tubules suffered from cloudy swelling (blue arrow) (H\&E Stain X20). D (L-C prophylaxis group): showing mild cloudy swelling of some renal tubules (blue arrow), another tubules showing dilatation (green arrow) and somewhat normal glomeruli (H\&E Stain X20). E (M.O treatment group): showing mild congestion of glomeruli (red arrow) and proteinous casts in lumen of some renal tubules (black arrow) (H\&E Stain X20). F (L-C treatment group): Showing nearly normal glomeruli and renal tubules (H\&E Stain X 20). 


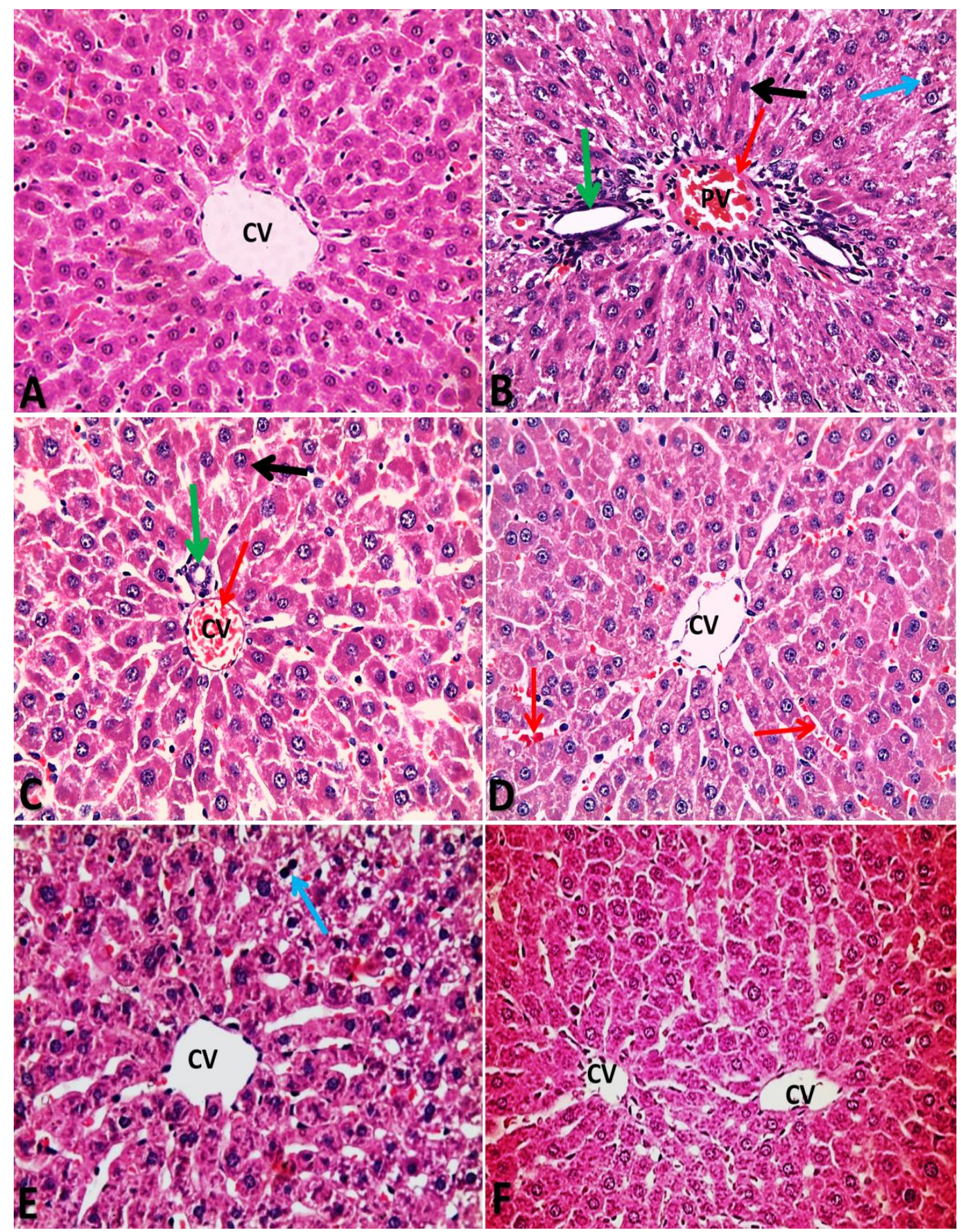

Fig. (2): Liver of different groups of rats: A (control): showing normal histological architectures (H\&E Stain X40). B (Cisplatin group): showing congestion of the portal vein (red arrow), newly formed bile duct with lymphocytic cells infiltration in portal area (green arrow) and coagulative necrosis of some hepatocytes (black arrow) and another showing hydropic degeneration (blue arrow) (H\&E Stain X20). C (M.O prophylaxis group): showed mild congestion of central vein (red arrow), mild coagulative necrosis of some hepatic cells (black arrow) and mild newly formed bile duct (green arrow) (H\&E Stain X20). D (L-C prophylaxis group): showed mild congestion of hepatic sinusoids (red arrow) with somewhat normal hepatic cells (H\&E Stain X20). E (M.O treatment group): showed mild hydropic degeneration of some hepatic cells (blue arrow) and other hepatocytes showed normal appearance (H\&E Stain X20). F (L.C treatment group): showing normal liver tissue (H\&E Stain X20).

\section{DISCUSSION:}

Our results revealed that cisplatin induced significant increase in serum ALT, AST, Urea and Creatinine levels. The elevation in serum ALT indicates cell membrane damage while the elevation in serum AST indicates mitochondrial damage, since mitochondrial
AST form $80 \%$ of the hepatic AST enzyme (Gaona et al., 2011). Evidence of cisplatininduced liver injury has been demonstrated by various studies (Işeri et al., 2007; Liao et al., 2008).

Cisplatin induced hepatotoxicity may be due to the accumulation of free radicals and oxidative 
deterioration of membrane polyunsaturated fatty acids in different tissues resulting from an increased lipid peroxidation and decrease the antioxidant defense system which lead to oxidative damage of the cells (Yilmaz et al., 2005; Mansour et al., 2006; Lu and Cederbaum, 2006).

The elevation in serum urea and Creatinine levels was thought to be due to irreversible renal tubular damage, necrosis and the impairment of urea and creatinine clearance. This result was in accordance with previous studies (Ince et al., 2014; Danduga et al., 2015).

In the present study, it was shown that treatment with cisplatin caused nephrotoxicity in rats, as evidenced by the high biochemical parameters such as high lipid peroxidation (MDA) and low antioxidant activity (Catalase and glutathione) and by histopathological changes as well. Many studies have reported similar structural changes in the kidney (An et al., 2011; Peres and da Cunha, 2013; Amirshahrokhi and Khalili, 2015)

The protective effects of 1-carnitine can be explained by its radical scavenging and enzymatic decomposition of oxygen metabolites and its important role in preventing lipid peroxidation and hydroxyl radicals formation and in protecting the structure and function of proteins, DNA and chromosomes against oxidation injury thus protect the integrity and functioning of tissues and cells (Lee et al., 2014).

Bajpai et al., 2005 was found that ethanol extracts of Moringa have antioxidant activity. Also, it was reported that the major bioactive compounds of phenolic, such as quercetin and kaempferol are responsible for antioxidant activity, prevents free radical generation, membrane lipid peroxidation and protecting biological membrane from damage (Alhakmani et al., 2013; Vongsak et al., 2014).

\section{CONCLUSION:}

Results of our study revealed that cisplatin intoxication induced nephrotoxic and hepatotoxic effect in rats as evidenced by the recorded serum biochemical alterations, oxidative stress, renal and hepatic histopathological alterations. Supplementation with 1-carnitine or Moringa provided a nephroprotective and hepatoprotective effect against cisplatin.

\section{REFERENCES:}

Aebi, H. (1974): Catalase. In: Bergmeryer, H.U. and Ulrich, H. " Methods of Enzymatic Analysis ". (2 ${ }^{\text {nd }}$ ed.)., Verlag Chemic, Weinhein, New York, pp.673.

Aleisa, A.M.; Al-Majed, A.A.; Al-Yahya, A.A.; Al-Rejaie, S.S.; Bakheet, S.A.; Al- Shabanah, O.A. et al. (2007): Reversal of cisplatin-induced carnitine deficiency and energy starvation by propionyl-L-carnitine in rat kidney tissues.Clin. Exp. Pharmacol. Physiol.34:1252-1259.

Alhakmani, F.; Kumar, S.; Khan, S.A. (2013): Estimation of total phenolic content, in - vitro antioxidant and antiinflammatory activity of flowers of Moringa oleifera.Asian Pac J Trop Biomed 3: 623-627.

Al-Majed, A.A. (2007): Carnitine deficiency provokes cisplatin-induced hepatotoxicity in rats. Basic Clin.Pharmacol.Toxicol. 100: 145-150.

Amirshahrokhi, K. and Khalili, A.R. (2015): Thalidomide ameliorates cisplatin-induced nephrotoxicity by inhibiting renal inflammation in an experimental model. Inflammation. 38: 476-484.

An, Y.; Xin, H.; Yan, W.; Zhou, X.X. (2011): Amelioration of cisplatininduced nephrotoxicity by pravastatin in mice. Exp. Toxicol. Pathol. 63: 215219.

Atessahin, A.; Karahan, I.; Turk, G.; Gür, S.; Yilmaz, S.; Ceribasi, A.O. (2006): Protective role of lycopene on cisplatininduced changes in sperm characteristics, testicular damage and oxidative stress in rats. Reprod. Toxicol. 21: 42-47.

Bajpai, M.; Pande, A.; Tewari, S.K. and Prakash, D. (2005): Phenolic contents and antioxidant activity of some food and medicinal plants. Int. J. Food Sci. Nutr., 56: 287-291.

Bancroft, J.D.; Suvarna, K.; Layton, C. (2012): Bancroft's theory and practice 
of histological techniques. $7^{\text {th }}$ ed. 2012 E books ISBN: 978-0-7020-5032-9.

Busani, M.; Patrick, J.m.; Voster, M. (2012): Antimicrobial activities of Moringa oleifera Lam leaf extracts. African Journal of Biotechnology. 11(11):2797-2802.

Cao, Y.; Qu, H.j.; Li, P.; Wang, C.b.; Wang, L.X.; Han, Z.w. (2011): Single dose administration of L-carnitine improves antioxidant activities in healthy subjects. Tohoku J Exp Med. 224: 209213.

Chanarian, I. (1989): " Textbook of laboratory Haematology: An Account of Laboratory Techniques" Churchill Livingstone New York, pp. 107-109.

Chinedu, A. A. ; Alani, S. O. ; Olaide, A. O. (2014): Effect of the ethanolic leaf extract of Moringa oleifera on insulin resistance in streptozotocin induced diabetic rats. Journal of Plant Sciences; 2(6-1): 5-12.

Danduga, R.C.R.; Kumar, G.S.; Kumar, K.P.; Swamy, B.M.V.; Kishore, K.V. (2015): Nephroprotective activity of Cissampelos pareira Linn. extract against cisplatin induced nephrotoxic rats. Am. J. Pharm. Tech. Res. 5: 480488.

Eken, H.A.; Koç, E.R.; Yazici, H.; Yay, A.; Önder, G.Ö.; Sarici, S.F. (2014): Selenium partially prevents cisplatininduced neurotoxicity: a preliminary study. Neurotoxicology. 1942.715.

Fabiny, D.L. and Eringhausen, G. (1971): Calorimeteric method for estimation of creatinine. Clin. Chem., 17:696.

Gaona, L.G.; Jijon, E.M.; Tapia, E.; Zazueta, C.; Pando, R.H.; Oliver, M.C.; Marquez, G.Z.; Pinzon, E.; Chaverri, J.P. (2011): Protective effect of sulforaphane pretreatment against cisplatin-induced liver and mitochondrial oxidant damage in rats. Toxicology.286: 20- 27.

Hagar, H.; El Medany, A.; Salam, R.; El Medany, G.; Nayal, O.A. (2015): "Betaine supplementation mitigates cisplatin-induced nephrotoxicity by abrogation of oxidative/nitrosative stress and suppression of inflammation and apoptosis in rats,"Experimentaland Toxicologic Pathology, vol. 67, no. 2, pp. 133-141.

Hamza, A.A. (2010). Ameliorative effects of Moringa oleifera Lam seed extract on liver fibrosis in rats. Food Chemistry and Toxicology. 48:345-355.

Ince, S.; Arslan Acaroz, D.; Neuwirth, O. et al. (2014): "Protective effect of polydatin, a natural precursor of resveratrol, against cisplatin induced toxicity in rats," Food and Chemical Toxicology, vol. 72, pp. 147-153.

Iseri, S.; Ercan, F.; Gedik, N.; Yuksel, M.; Alican, I. (2007): Simvastatin attenuates cisplatin-induced kidney and liver damage in rats. Toxicology. 230:256-264.

Kolodziejczyk, J.; Saluk-Juszczak, J.; Wachowicz, B. (2011): L-carnitine protects plasma components against oxidative alterations. Nutrition.27:6939.

Lee, B.J.; Lin, J.S.; Lin, Y.C.; Lin, P.T. (2014): Effects of L-carnitine supplementation on oxidative stress and antioxidant enzymes activities in patients with coronary artery disease: a randomized, placebo-controlled trial. Nutr J.13: 1.

Leone, A.; Spada, A.; Battezzati, A.; Schiraldi, A.; Aristil, J.; Bertoli, S. (2015): Cultivation, genetic, ethnopharmacology, phytochemistry and pharmacology of Moringa oleifera leaves: An overview. International journal of molecular sciences. 16(6), 12791-12835.

Liao, Y.; Lu, X.; Lu, C.; Li, G.; Jin, Y.; Tang, H. (2008): Selection of agents for prevention of cisplatin-induced hepatotoxicity. Pharmacol Res. 57: 125-131.

Lile, E.C.; Villamil, M.F.; Rhees, M.C. and Scribner, B.H. (1957): Determination of urea nitrogen level in serum or plasma J.A.M.A. 1957; 164 (3): 277 - 279. Doi: 10.1001/ jama. 1957.62980030001013.

Lu, Y. and Cederbaum, A.I. (2006): Cisplatin-induced hepatotoxicity is 
enhanced by elevated expression of cytochrome P450 2E1. Toxicol Sci. 89:515-23.

Ma, X.; Yan, L.; Zhu, Q.; Shao, F.; Mukhopadhyay, P. (2017): "Puerarin attenuates cisplatin-induced rat nephrotoxicity: The involvement of TLR4/NF- $\kappa \mathrm{B}$ signaling pathway," PLOS ONE, vol. 12, no. 2, p. e0171612.

Mansour, H.H.; Hafez, H.F.; Fahmy, N.M. (2006): Silymarin modulates Cisplatininduced oxidative stress and hepatotoxicity in rats. J.Biochem.Mol.Biol. 39:656-661.

Ohkawa, H.; Onishi, N.; Yagi, K. (1979): Assay for lipid peroxidation in animal tissue by thiobarbituric acid reaction. Anal Biochem. 95:351-8.

Ouedraogo, M.; Lamien-sanou, A.; Ramde, N. et al. (2013): Protective effect of Moringa oleifera leaves against gentamicin induced nephrotoxicity in rabbits. Exp Toxicol Phathol 65: 335339.

Paliwal, R.; Sharma, V.; Pracheta-Sadhna, S. (2011): Elucidation of free radical scavenging and antioxidant activity of aqueous and hydro-ethanolic extracts of Moringa oleifera pods. Res J Pharmacy Technology. 4: 566-571.

Peres, L.A. and da Cunha, A.D. (2013): Acute nephrotoxicity of cisplatin: molecular mechanisms. J Bras Nefrol. 35:332-40.

Reedijk, J. (2011): Increased Understanding of platinum Anti-cancer Chemistry, Pure and Applied Chemistry. 83(9): 1709-1719.

Reitman, S. and Frankel, S. (1957): A coloimetric method for the determination of serum glutamic oxaloacetic and glutamic pyruvic transaminases. Am. J. Clin. Path., 28:56-62.

Saleh, R.M.; Awadin, W.F.; Elseady, Y.Y.; Wehaish, F.E. ( 2014): Renal and cardiovascular damage induced by cisplatin in rats. Life Sci. J.11 (5).

Schermer, S. (1967): The Blood Morphology of Laboratory Animals. $3^{\text {rd }}$ ed., F. A. Davi, Philadelphia p: 42.

Sendecor, G.W. and Cochran, W.G. (1987): The Comparison of Two Samples. Statistical methods $4^{\text {th }}$ ed, pp. 91-110. Iowa state University.

Sharma, V.; Paliwal, R.; Janmeda, P.; Sharma, S. (2012): Renoprotective effects of Moringa oleifera pods in 7, 12 dimethylbenz[a] anthracene exposed mice, J Chin Int Med, 10, 1171-8.

Sleem, M.; Tayea, A.; El-Moselhya, M. A.; Mangoura, S. A. (2014): Combination therapy with losartan and L-carnitine protects against endothelial dysfunction of streptozotocin-induced diabetic rats. European Journal of Pharmacology; 744 (2014) 10-17.

Ugur, S.; Ulu, R.; Dogukan, A. et al. (2015): "The renoprotective effect of curcumin in cisplatin-induced nephrotoxicity," Renal Failure, vol. 37, no. 2, pp. 332-336.

Vongsak, B.; Sithisam, P.; Gritsanapan, W. (2014): Simultaneous HPLC quantitative analysis of active compounds in leaves ofMoringa oleifera Lam. J Chromatogr Sci. 52: 641- 645 .

Waseem, M.; Bhardwaj, M.; Tabassum, H.; Raisuddin, S.; Parvez, S. (2015): Cisplatin hepatotoxicity mediated by mitochondrial stress. Drug Chem Toxicol. 38(4):452-429.

Yilmaz, H.R.; Sogut, S.; Ozyurt, B.; Ozugurlu, F.; Sahin, S.; Isik, B. et al. (2005): The activities of liver adenosine deaminase, xanthine oxidase, catalase, superoxide dismutase enzymes and the levels of malondialdehyde and nitric oxide after cisplatin toxicity in rats: protective effect of caffeic acid phenethyl ester. Toxicol Ind. Health. 21:67-73. 